\title{
YUsing SCAMPER-6ased Activities in Teaching Story to Enhance EFL Primary Stage pupils' Speaking Skills (An Exploratory Study)
}

Ghada Anis Fahmy , Prof. Aly Abdul-Samea Qoura, Dr. Samah Rizk Hassan

Mansoura University , Faculty of Education, Department of Curriculum \& Instruction

\section{Abstract}

$T$ The purpose of this study was to examine the effect of using SCAMPER-based activities in teaching story in developing EFL primary stage pupils' Speaking Skills .The study adopted the quasi-experimental design that involved two groups; an experimental group and a control group. The sample of the study consisted of sixty pupils randomly selected from six grades Fakhr Dakahlia Language School in Mansoura city, thirty pupils represented the control group and thirty pupils represented the experimental group. The current study was delimited to the Creative Speaking Skills. To fulfill this purpose the researcher designed and used two instruments; a prepost test for measuring the pupils' Creative Speaking Skills and a rubric. SCAMPER-based activities were administered to the experimental group for eight weeks, whereas the control group was taught in the traditional way. Results of the study indicated that there was a statistically significant difference between the mean scores of the experimental and control group in the post administration of the Creative Speaking Skills in favor of the experimental group. This revealed that the use of SCAMPER strategy led to a significant improvement in the pupils' Creative Speaking Skills. Therefore, it was recommended that Ministry of Education should hold trainings for EFL teachers in using SCAMPER strategy in teaching story, in order to help their pupils develop their Speaking Skills.

Key words: SCAMPER strategy, Creative Speaking Skills.

\section{Introduction:}

The world has become a small village. Globalization is the term of the present era. As a result, English has increasingly become a major medium of communication. So, the demand for English speakers is necessary in all countries. It has become apparent that students of English as a foreign language have considered themselves good and successful learners if they can communicate fluently and effectively in English (Graves, 2008). 
Hybel \& Richard (2000 p.56) define speaking as "any process in which people share information, ideas, and feelings, it involves all of body's language, mannerism and style ". Nunan (2003) defines speaking as a productive oral skill. It consists of producing systematic verbal utterances to convey meaning. He added that success in learning a language is measured in terms of the ability to carry out a conversation in the target language.

Speaking is mostly taught with old fashioned teachercentered approaches that stress memorization of conversations from the text books. So students are not given the opportunity to think and express their ideas freely. Therefore, teachers play an important role in developing oral language by creating opportunities for learners to talk in an environment that facilitates oral expression.

Teaching story has always been a way used by a majority of people around the world who like their children to enjoy a character's adventures and to distinguish between good and evil. It encourages primary school students to broaden their minds and think creatively. Murdoch (2002, p.9) indicates that short stories can provide quality text content which will greatly enhance English language teaching courses for learners at intermediate levels of proficiency.

Recently, many new strategies have been greatly developed to encourage the positive interaction between the student and the teacher, and enhance the concept of creativity so the learner could be able to think creatively to solve the problems. Among these strategies is SCAMPER in which students will:

1. S: substitute

2. C: combine

3. A: adapt

4. M: modify

5. P: put to use

6. E: eliminate

7. R: reverse. 
SCAMPER strategy offers a systematic and practical way to stimulate divergent thinking, imagination, originality, and intuition while scaffolding students, creative thinking for independent use or other tasks and assignments. (Glenn, 1997).

\section{Review of literature}

\section{Speaking:}

Speaking is one of the four language skills .Speaking in a second or foreign language has often been viewed as the most demanding of the four skills (Baily \& Savage 1994). According to Lindsay \& Knight (2006), speaking is communicating the message, and interacting with other people.

\section{The nature of Speaking:}

Rizfi (2006 , 92) defined speaking as an interactive communicative process that involves speakers and listeners. It is not the oral production of written language but involves learners in the mastery of a wide range of sub-skills, which, added together, constitute an overall competence in the spoken language (McDonough and Shaw, 2003,13$)$.

Richards and Renandya (2002: 204) say that learning to speak a foreign language is more than knowing its grammatical and semantic rules. Learners must also acquire the knowledge of how native speakers use the language in the context of structured interpersonal exchange in which many factors interact.

\section{Speaking sub skills:}

According for Widiastuti ( 2008 ) , Brown ( 2001 ) the Speaking sub Skills are:

\section{Comprehension:}

It is the process of understanding the utterances sent by the speaker.

\section{Grammar:}

Ur, (1996) defines Grammar as the way words are put together to make correct sentences. As for Widiastuti (2008), he 
defines Grammar as the students' ability to use structure and differentiate appropriate grammatical rules in a situation.

\section{Vocabulary:}

It is the total number of words which students use to express their ideas whether orally or in a written form. "Ones can't communicate successfully or state their thoughts mutually oral and written shape if they don't have enough vocabulary. Thus, vocabulary means the suitable pronunciation which is employed in communication" (Widiastuti, 2008).

\section{Pronunciation:}

Based on Longman Dictionary (2000: 429) pronunciation is the way a certain sound or sounds are produced. It covers the way for speakers to produce clear language when they speak.

\section{Fluency:}

Hughes (2002) defined fluency as "The capability of expressing oneself in an intelligible, reasonable and perfect way without extra hesitation, otherwise the communication will fail because listeners will lose their interest".

\section{Accuracy:}

Accuracy is an ability to produce sentences or utterance with correct grammar as stated in Longman Dictionary (2000: 204). The speakers need to follow the rules of the language such as grammar and structure to be able to speak accurately.

\section{Activities for enhancing the Speaking Skill:}

Anna ( 2010 ) , Jondeya (2011), Harmer ( 2002 ) , Kayi (2006) and Thonnbury ( 2005 ) identified some activities which are proved to enhance the students' Speaking Skill :

\section{Discussion:}

Brown (2004:175) states that discussion can promote some skills such as topic nomination, maintenance, and termination; attention getting, interrupting, control; clarifying, questioning, paraphrasing, comprehension signals; negotiating meaning; intonation patterns for pragmatic effect; kinesics, eye contact, 
proxemics, body language; and politeness, formality, and other sociolinguistic factors.

\section{Games:}

The use of games in teaching a foreign language gives opportunities to build and develop the skills of independent creative activity (Konisheva, 2008) .Anna (2010) stated that games consist of many factors that are useful in improving Speaking such as instructions, competitions, recreation, and language learning.

\section{Role- play:}

Using role-playing in the classroom allows the teacher to create and develop the students' skills and the ability to find the necessary information, transform it, to produce plans on the basis of it and decisions in non-stereotypical situations. It helps to ensure mutual communication of all participants and motivating speaking activity (Kovalenko and Anna Smirnova, 2015).

\section{Interviews:}

Students can conduct interviews with many persons on various topics. It is advisable that the teacher provides a rubric for the students, so they know what to do, but they should prepare the interview questions by themselves.

\section{Information gap activities:}

Information gap activities is a communicative teaching strategy which has been recommended by language researchers for teaching Speaking. When conducting information gap activities, teachers work as facilitators providing students with skills they need, organizing the classroom activities, correcting students' errors and observing the students to discover their strengths and weaknesses to propose future activities ( Jondeya ,2011).

\section{Storytelling:}

Storytelling hones our literary and imaginative skills. We improve our ability to listen, speak, imagine, compose phrases 
and create stories. It broadens our awareness of our own as well as other cultures, allows us to understand ourselves better, gives us a sense of belonging to a group and increases our vocabularies (McDonald, 1993).

\section{Acting from a script:}

This type of activity allows the teacher to ask the students to act out scenes from plays, course books or dialogues written by themselves. By giving students practice in these things before they gave their performances, it means that acting out is both learning and language producing activity.

\section{Prepared talk:}

This activity allows a student (or group of students) make a presentation on a topic of their own choice. The talks are not designed for informal spontaneous conversation. This activity represents a defined and useful speaking genre and can be extremely interesting for both speaker and listener if properly organized.

\section{Questionnaires:}

This type of activity allows the students to design questionnaires of any appropriate topic. The results obtained from questionnaire can form the basis of written work, discussions, or prepared talks.

Many studies were conducted by different researchers to develop and improve the Speaking Skill using different techniques. The following lines preview some of these studies.

Tilahun, (2013) study was to identify the challenges of teaching speaking skill in a large English language classroom. 100 grade nine students were involved in the study. The study shows that there are a number of challenges that contribute not to practice teaching speaking skill in large English language classrooms. According to the findings, there are a number of problems that challenge them to practice it such as the nature of chairs and desks which are not moveable, the students lack of adequate motivation and courage to speak, the failure of classroom teachers to be committed and use their effort in the 
teaching learning process, failures of teachers and students to use different strategies in order to make speaking classroom convenient and effective are some of them.

Diyyab (2013) investigated the effectiveness of using a multimedia-based program for developing EFL speaking fluency skills among second year, English section student teachers. The sample of the study consisted of thirty students at Sadat Faculty of Education, Minufiya University, Egypt Results of the study revealed that the study sample's EFL speaking fluency skills were developed after using the program.

\section{SCAMPER strategy}

SCAMPER strategy is based on the notion that everything new is a modification of something that already exists. It is considered a creative problem-solving technique or strategy which allows users to break free from rigid and limited thinking patterns and operate in various ways (Moreno, Hernández,Yang, \& Wood, 2014).

\section{SCAMPER rationale:}

First proposed by Alex Osborne in 1953, this thinking strategy was further developed by Bob Eberle and noted in his 1971 book, SCAMPER: Games for Imagination Development. Eberle states that much as the word scamper suggests "running playfully about as a child", the strategy SCAMPER may also evoke the need "to run playfully about in one's mind in search of ideas" (Eberle, 1984).

SCAMPER strategy offers a systematic and practical way to stimulate divergent thinking, imagination, originality, and intuition while scaffolding students' creative thinking for independent use on other tasks and assignments (Glenn, 1997). Instead of focusing on reading and research, SCAMPER is a framework for creative questioning that can apply to almost any situation at home or school (Eberle, 1987).

The questions generated by SCAMPER can be used to address many types of problems. Students do not have to sit and 
wait for ideas to pop into their heads, but can use SCAMPER questions to help the ideas come .SCAMPER can be used to modify and elaborate story plots, create ideas for threedimensional art projects, or address school or community problems .It gives students a set of tools they can use when they are struggling to find an idea or to improve the ideas they have (Starko, 2014,157 ).

\section{SCAMPER principles:}

Michalko, (2006) stated that each of the letters in the acronym SCAMPER stands for a stage in the process. They include the following principles:

1. S Substitute: Substitutions is a trial-and-error method where you can try things out, see if it works, then try something different.

2. C Combine: Combining involves synthesis, the process of combining previous ideas or things together to create something new.

3. A Adapt: Thinking about what is already known about the problem and how others are solving it. Become aware of the process others are using.

4. M Modify: (also magnify or minify) When you modify and alter something, you reflect on what is needed to support and make it better, greater, simpler, or even more complicated.

5. P Put to other uses: Considering ways that the target can be used other than originally intended.

6. E Eliminate: (also, elaborate) To remove or omit part or all of a particular quality to add more details.

7. $\mathrm{R}$ Reverse :( also, Rearrange)

When using reverse, the focus is on the opposite or contrary meaning. When using rearrange, the focus is on how the change of order or sequence would affect the target or challenge.

SCAMPMER principles were clarified by Michalko (2006) in the following organizer : 
Figure (1) SACMPER organizer (Michalko, 2006)

\begin{tabular}{|c|c|c|}
\hline $\mathbf{S}$ & Substitute & $\begin{array}{l}\text { Sample questions: } \\
\text {-What can I substitute } \\
\text { - Who can I substitute }\end{array}$ \\
\hline C & Combine & $\begin{array}{l}\text { Sample questions : } \\
\text { - Combine ideas /purposes /materials? } \\
\text { - Can anything be blended or ensemble? }\end{array}$ \\
\hline A & Adapt & $\begin{array}{l}\text { Sample questions: } \\
\text { How the problem is currently solved? - } \\
\text { - How can it be made more accommodating? } \\
\text { - How can it be more compatible? }\end{array}$ \\
\hline M & Modify & $\begin{array}{c}\text { Sample questions: } \\
\text { - How can this be altered for the better? } \\
\text {-What can I modify? } \\
\text {-Modify color / shape? } \\
\text { - Change motion or sound? }\end{array}$ \\
\hline $\mathbf{P}$ & $\begin{array}{l}\text { Put to other } \\
\text { uses }\end{array}$ & $\begin{array}{c}\text { Sample questions: } \\
\text { - What else can this be used for? } \\
\text { - What are those uses? } \\
\text { - Who else could use it? }\end{array}$ \\
\hline $\mathbf{E}$ & Eliminate & $\begin{array}{c}\text { Sample questions: } \\
\text { - What should I simplify or enrich? } \\
\text { - Should it be plain or fancy? } \\
\text { - How can I do these? }\end{array}$ \\
\hline $\mathbf{R}$ & Reverse & $\begin{array}{l}\text { Sample questions : } \\
\text { - What other time, routine, process, place? } \\
\text {-What other arrangements might be better? } \\
\text { - What would happen if I flipped the order? } \\
\text { - Rearrange the sequence, layout, or pattern? }\end{array}$ \\
\hline
\end{tabular}

\section{How to use SCAMPER:}

When using this strategy in the classroom, it will be helpful for the teacher to:

1. Review the SCAMPER acronym with its associated questions.

2. Have a sheet of paper with SCAMPER acronym and the associated words.

3. A list of the questions for each SCAMPER word to be used by the pupils.

Michalko (2006) stated two steps when applying SCAMPER in the classroom: 


\section{First: Defining the goal / challenge:}

Presenting the idea / process/ problem / that we want to change.

\section{Second: Using SCAMPER strategy:}

1. Directing the pupils to use principles of SCAMPER using some helper questions and the SCAMPER organizer.

2. Group members call out their answers for discussion. Any response to the SCAMPER strategy is welcomed no matter how non-logical it is.

Many researchers investigated the use of SCAMPER in developing Creativity and Creative Thinking such as Dee and Barkley (2001) who investigated the enhancement of the skills of decision making and problem solving of the teachers in service. SCAMPER strategy was used, and it proved to be fruitful in improving the teachers' abilities of decision making and problem solving.

Bakr (2004) used SCAMPER strategy with other four strategies to develop creative thinking of English learners at the preparatory stage. The study was conducted on a sample of 70 students of $2^{\text {nd }}$ year preparatory stage. It investigated the efficacy of some proposed activities for developing Creative Thinking of English learners. The results showed high achievement in English language and improvement in the learners' creative thinking.

Hussein \& Carignan (2016) study explored to what extent the SCAMPER strategy activities can help fourth graders generate creative ideas while augmenting their inventiveness. The sample consisted of 24 fourth grade students at a suburban Midwestern elementary school. A repeated-measures design involving all participants alternately in the two conditions measured students under each treatment condition. In the experimental condition, students used SCAMPER charts with animal adaptation ideas to generate ideas to improve a product using limited materials; in 
the control condition, they used simple SCAMPER charts to improve a product with limited materials. A scoring rubric was designed to assess the utilization of the SCAMPER chart and students' inventiveness. Students' inventiveness scores showed a statistically significant difference favoring the experimental condition. In contrast, student scores for completing the two types of SCAMPER charts favored the simpler control condition's chart. However, student products completed under the experimental condition showed more complexity and originality.

The previous studies showed that SCAMPER strategy has been mainly used to develop Creativity and Creative Thinking Skills. In this exploratory study, SCAMPER strategy was used in teaching story to develop the Creative Speaking Skills of the primary stage pupils in governmental language schools.

\section{Creative Speaking:}

Nunan (2015) drew a distinction between reproductive speaking and Creative speaking. In reproductive speaking, the learners reproduce language forms and cues provided by the teachers or some other aural models. In creative language use, the learners do not regurgitate the meanings of others, but create their own meanings .Both reproductive and creative are necessary in developing speaking. Often students prefer reproductive oral work because it is safer, as the risk of making mistakes is minimized. Therefore, good teachers should create a non-threatening environment and encourage learners to leave their comfort zone and engage in tasks that require creative language use.

A Creative Speaking approach was developed by Becker and Roos (2016) with the aim to promote productive language use in the young learners' classroom. It is illustrated in the model in Fig. (2) And is described in the following sections. 


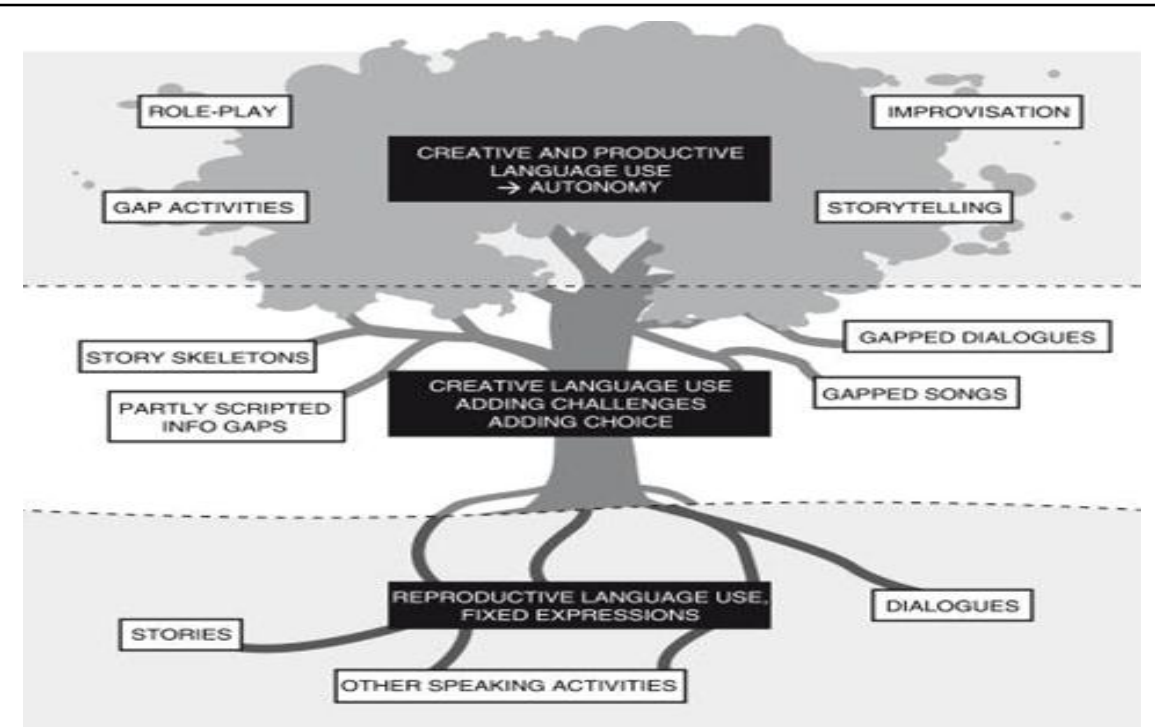

Figure (2) :An approach to Creative Speaking. (Becker and Roos 2016)

\section{Level I: Reproductive language use}

The model is organized across three levels. At the first level, reproductive language use, it integrates activities that foster reproductive language use, which is considered an important foundation of creative speaking. At this level, the learners use fixed expressions in order to be able to communicate successfully. Activities are guided as well as closely linked to the input given in class. They mainly promote imitation and therefore include saying rhymes and chants, singing songs and retelling stories or parts of stories and scripted acting and speaking of dialogues, role plays and sketches. They also include other speaking activities such as guided information-gap activities, where the language to be used is fully supplied. Guided activities are very motivating because they allow beginning learners to speak imitatively and to actively participate from a beginning level on.

\section{Level II: Creative language use}

The next level, Creative Language Use, allows learners to practice control" (Thornbury 2005b, 63) over their individual 
language repertoires Thornbury (2005 b, 63) describes "practiced control" as "demonstrating progressive control of a skill where the possibility of making mistakes is ever-present, but where support is always at hand."

The main goal of practicing control is to support appropriation of the target language. According to Thornbury (2005b, 63), "learning a skill is not simply a behavior (like practice) or a mental process (like restructuring) . Central to the notion of a transfer of control is the idea that aspects of the skill are appropriated. Appropriation has "connotations of taking over the ownership of something, of 'making something one's own' (Thornbury 2005b, 63). In order to facilitate appropriation, the learners have to independently perform and creatively combine fixed expressions, but can still rely on support through the provision of partial scaffolding in form of phrases they are provided with. Examples of such activities include partly scripted guessing games and information-gap activities, story skeletons and gapped songs, chants or rhymes.

\section{Level III: Creative and Productive language use}

Activities at Level III promote creative and productive language use and challenge learners to use the individual linguistic repertoire available to them in a meaningful context. This means that they are free to rely on rote-learned expressions, to creatively combine them or to use language totally creatively in order to find their own ways of expressing meaning. Possible activities include non-scripted information-gap activities such as picture differences tasks, opinion-gap tasks, non-scripted storytelling, role play and improvisation tasks. All activities at that level require that the learners "marshal their newly acquired skills and deploy them unassisted" (Thornbury 2005b, 13). They also need to spontaneously interact with peers, retrieve appropriate language structures, cope with unpredictability, anticipate and plan ahead. Therefore, the learners are challenged to perform independently and can experience a very high degree of autonomy. Partly scripted activities from Level II can easily be modified by removing the support to make them suitable for 
Level III. The reduced support and freedom of language use at Level III inevitably leads to errors. In this context, however, it is important "to see errors as evidence of learners' progress, in the sense that they show that learners are making creative attempts to use language beyond what they have been taught" (Nicholas, Lightbown and Spada 2001, 720). Thornbury (2015b, 111) emphasizes that the learners need to be able to "experience autonomy" and experiment with language, but also need to be provided with effective and clear as well as discreet and sensitive feedback "for the improvement of the subsequent performance." Feedback should therefore always be given after carrying out activities at the third level. Instead of an overt correction, which can be very demotivating and inhibiting, feedback that focuses on improvement may be very helpful.

Nurhayati (2016) investigated using Local Drama in Writing and Speaking to enhance EFL Learners' Creative Expression .The study offered the variation performance in delivering ideas or activities through writing a script and conducting a drama. The steps of learning writing are (1) Creative Expression (responding to the ideas that learners produce; (2) Composing Process: planning-writing-reviewing framework using dramatic structure: orientation, complication, sequence of events, resolution and coda; (3) Genre and context of writing .In speaking, the students were divided into some groups to create the learning community, the steps are: create script based on themes, next consult the script (discuss their creative expression), observe the characters play, their characterization, mime, and other aspects, practice the script, and finally perform drama outdoor. The results showed more self-confidence in uttering ideas, which indicates that drama is considered as an appealing learning strategy.

The current study is delimited to the Creative Speaking Skills (CSS). To the farthest knowledge of the researcher, previous studies related to this variable are very rare .Therefore this study is considered an exploratory study. 


\section{Statement of the problem:}

In light of the review of literature, my experience as a teacher of English for eighteen years, and the results of the pilot study, it was observed that EFL primary stage pupils in Egyptian schools have difficulties in their creative speaking skills which hinder their ability to express new ideas fluently. There are many reasons that cause that poor level in the pupils' creative speaking skills, among these causes are the traditional approaches in teaching the English language which focus mainly on memorizing the textbook conversations in addition to the old- fashioned media of evaluation in which testing speaking skills is neglected.

\section{Questions of the study:}

The problem of this study could be stated in the following main question:What is the effectiveness of using SCAMPER strategy in teaching story to enhance the EFL speaking skills of primary school pupils?

For research purposes, this main question is subdivided into the following questions:

1. What are the creative speaking skills necessary for EFL primary stage pupils?

2. How can the suggested SCAMPER-based activities be used to develop the creative speaking skills of EFL primary stage pupils?

\section{Purposes:}

The current study aimed at:

1. Investigating the effect of using SCAMPER strategy in teaching story to improve the Creative Speaking Skills of the sixth year primary school pupils.

2. Designing SCAMPER -based activities to help EFL teachers teach the story according to the SCAMPER principles.

\section{Delimitations:}

This study was delimited to the following: 
1. Developing the Creative Speaking Skills of sixth year primary pupils, where pupils were able to change characters, events, and/or the sequence in the story in order to help them think and speak creatively.

2. A group of sixth year primary pupils in a governmental language school.

3. The first three chapters of the story taught to sixth year primary pupils in governmental language schools.

4. Some Creative Speaking Skills (fluency, flexibility, originality)

\section{Hypotheses:}

1. There is no statistically significant difference between the mean score of pupils of control and experimental groups in the pre- test of Creative Speaking Skills.

2. There is a statistically significant difference at 0.05 level between the mean score of pupils of control and experimental groups in the post test of creative speaking skills in favor of the experimental group.

3. There is a statistically significant difference at 0.05 level between the mean score of the pre and post administration of the experimental group in Creative Speaking Skills in favor of the post test.

\section{Methods:}

\section{Participants:}

Sixty pupils of sixth year primary school participated in the study. They were divided into two equal groups, in two separate classes as follows:

1. The experimental group to which the story is taught using SCAMPER strategy.

2. The control group to which the story is taught in the traditional method.

\section{Instruments:}

1. A pre-post test for measuring the EFL creative speaking skill of the sixth year primary pupils designed by the researcher. 
2. A Creative Speaking Skills Rubric to score the pupils' CSS during the pre- post test.

\section{Design:}

The researcher followed the quasi-experimental design in which the participants were divided into two groups; experimental group and control group. The experimental group was taught the story using SCAMPER strategy, whereas the control group was taught the story using the traditional way.

\section{Results and discussion}

\section{Testing the first hypothesis}

"There is no statistically significant difference between the mean score of pupils of control and experimental groups in the pre- test of Creative Speaking Skills". A Creative Speaking pretest was administered on the experimental and control groups and the Creative Speaking Rubric was used to identify the mark of each question. Results were analyzed statistically to ensure the homogeneity of both groups.

Table (1): T-Test results of the pre administration of the pre-post test comparing the scores of the experimental and the control group

\begin{tabular}{|c|c|c|c|c|c|c|}
\hline Test skills & Group & Numbers & Mean & $\begin{array}{c}\text { Std. } \\
\text { Deviation } \\
\end{array}$ & $\begin{array}{c}\text { T- } \\
\text { Value }\end{array}$ & Significance \\
\hline \multirow[t]{2}{*}{ Fluency } & $\begin{array}{l}\text { Experi } \\
\text { mental }\end{array}$ & 30 & 11.1 & 0.96 & 0.19 & $\begin{array}{c}\text { None } \\
\text { significant }\end{array}$ \\
\hline & Control & 30 & 11.23 & 3.49 & & \\
\hline \multirow[t]{2}{*}{ Flexibility } & $\begin{array}{l}\text { Experi } \\
\text { mental }\end{array}$ & 30 & 10.23 & 1.01 & 0.15 & $\begin{array}{c}\text { None } \\
\text { Significant }\end{array}$ \\
\hline & Control & 30 & 10.29 & 1.83 & & \\
\hline \multirow[t]{2}{*}{ Originality } & $\begin{array}{l}\text { Experi } \\
\text { mental }\end{array}$ & 30 & 9.17 & 0.38 & 0.87 & $\begin{array}{c}\text { None } \\
\text { Significant }\end{array}$ \\
\hline & Control & 30 & 9.30 & 0.75 & & \\
\hline $\begin{array}{c}\text { Total } \\
\text { degree }\end{array}$ & $\begin{array}{l}\text { Experi } \\
\text { mental }\end{array}$ & 30 & 16.32 & 4.43 & 0.67 & $\begin{array}{c}\text { None } \\
\text { Significant }\end{array}$ \\
\hline of the test & Control & 30 & 15.88 & 4.11 & & \\
\hline
\end{tabular}

Table (1) shows that the mean scores of the experimental and control groups were almost equivalent in all three skills. This indicates the homogeneity of both groups. The values are between 0.15 and 0.87 . The results substantiate the first 
hypothesis of the study.So, any variance between the two groups that may happen after the implementation of the experiment could be attributed to the effect of SCAMPER-based activities.

\section{Testing the second hypothesis}

"There is a statistically significant difference at 0.05 level between the mean score of pupils of control and experimental groups in the post test of creative speaking skills in favor of the experimental group". In order to test this hypothesis, the t-test for two independent groups was used to compare the scores of the study. Results are represented in table (2):

Table (2): A comparison of the experimental and control performance on the pre-post Creative Speaking Test

\begin{tabular}{|c|c|c|c|c|c|c|c|}
\hline $\begin{array}{c}\text { Test } \\
\text { Skills }\end{array}$ & Group & No. & Mean & $\begin{array}{c}\text { Std. } \\
\text { Deviation }\end{array}$ & $\begin{array}{c}\text { T- } \\
\text { Value }\end{array}$ & D.F & Sig. \\
\hline Fluency & $\begin{array}{c}\text { Experi } \\
\text { mental }\end{array}$ & 30 & 28.00 & 3.895 & 6.942 & 58 & 0.05 \\
\hline & Control & 30 & 22.37 & 2.141 & & 58 & \\
\hline $\begin{array}{c}\text { Flexibilit } \\
\text { y }\end{array}$ & $\begin{array}{c}\text { Experi } \\
\text { mental }\end{array}$ & 30 & 23.10 & 3.252 & 6.927 & 58 & 0.05 \\
\hline & Control & 30 & 18.30 & .651 & & 58 & \\
\hline $\begin{array}{c}\text { Originali } \\
\text { ty }\end{array}$ & $\begin{array}{c}\text { Experi } \\
\text { mental }\end{array}$ & 30 & 22.83 & 3.779 & 5.589 & 58 & 0.05 \\
\hline & Control & 30 & 18.90 & .759 & & 58 & \\
\hline $\begin{array}{c}\text { Total } \\
\text { Score }\end{array}$ & $\begin{array}{c}\text { Experi } \\
\text { mental }\end{array}$ & 30 & 16.3241 & 4.4321 & 6.879 & 58 & 0.05 \\
\hline & Control & 30 & 15.883 & 4.1132 & & 58 & \\
\hline
\end{tabular}

Results in table (2) show that the experimental group outperformed the control group in the three sub skills of the Creative Speaking. The means of the fluency, flexibility and originality were relatively close at 28.00, 23.10, and 22.83 respectively. All differences between the experimental and the control group were significant at 0.05 levels. This means that using SCAMPER strategy in teaching story was effective in enhancing the pupils' Creative Speaking Skills.

\section{Testing the third hypothesis}

"There is a statistically significant difference at 0.05 level between the mean score of the pre and post administration of the experimental group in Creative Speaking Skills in favor of the post test". In order to test this hypothesis, the t-test for two 
independent groups was used. Results are represented in table (3).

\section{Table (3) A comparison of results of the pre/post administration of} the Creative Speaking Skills test of the experimental group

\begin{tabular}{|c|c|c|c|c|c|c|c|}
\hline Sub Skills & $\begin{array}{c}\text { Applica } \\
\text { tion }\end{array}$ & No. & Mean & $\begin{array}{c}\text { Std. } \\
\text { Deviation }\end{array}$ & T Value & D.F & Sig. \\
\hline Fluency & Pre & 30 & 11.10 & .960 & 63.362 & 29 & \\
\hline & Post & 30 & 28.00 & 3.895 & 39.372 & & 0.001 \\
\hline Flexibility & Pre & 30 & 10.23 & 1.006 & 55.699 & 29 & \\
\hline $\begin{array}{c}\text { Originalit } \\
\text { y }\end{array}$ & Post & 30 & 23.10 & 3.252 & 38.906 & & 0.001 \\
\hline & Pre & 30 & 9.17 & .379 & 132.458 & 29 & \\
\hline $\begin{array}{c}\text { Total } \\
\text { Score }\end{array}$ & Pre & 30 & 12.23 & 1.321 & 89.348 & 29 & \\
\hline & Post & 30 & 25.45 & 3.978 & 43.347 & & 0.001 \\
\hline
\end{tabular}

Table (3) reveals that the post administration of the test was substantially more significant than the pre administration of the experimental group in the three sub skills of the Creative Speaking test and in the total score of the test .All differences between the mean scores of the pre and post administration of the experimental group were significant at 0.05 level. This proves the effectiveness of using SCAMPER strategy in enhancing the pupils' Creative Speaking Skills.

\section{Discussion:}

Results of the current study add up to those of the previous studies conducted by Dee \& Barkley (2001), Bakr ( 2004 ), Hussein and Carignan ( 2016 ) in that they proved the effectiveness of using SCAMPER strategy in developing the pupils' creativity. The results are also consistent with the Creative Speaking approach developed by Becker \& Roos (2016) aiming to promote productive language use in the young learners' classroom. Results of the present study are evident that teaching story to primary stage pupils using SCAMPER strategy could help them improve their Creative Speaking Skills.

The main objectives of the proposed SCAMPER activities were to define what SCAMPER is, develop their Speaking skills, speak creatively, talk about new characters and events and retell 
the story in a creative language .The researcher adapted the questions based on the first three chapters of the pupils' storybook in the first term according to the seven principles of SCAMPER strategy; ( substitute, combine, adapt, modify, put to other uses ,eliminate, reverse ). Organizers of SCAMPER- based questions of each lesson were distributed and answered orally by the students who were sitting in groups of 4-5. Seven sessions were designed in addition to an introductory session in which pupils watched a YouTube video on SCAMPER. Copies of SCAMPER organizers were distributed in each session in which pupils read the helper questions and answered creatively. Pupils' age ranged between 11 and twelve. It is worth mentioning that during the implementation of the experiment, pupils were very responsive and could give unique and unexpected answers to some questions. The pupils' responses proved that the implementation of the strategy not only developed the pupils' Creative Speaking Skills, but also created a funny and enjoyable classroom atmosphere which helped in arousing the pupils' interest, developing the pupils' positive attitudes towards the learning of the English language developing the pupils' creative use of the language, enhancing the pupils' ability to work in groups, encouraging pupils to express their ideas freely, motivating the pupils to think and generate more ideas and developing the concept of "Thinking outside the box ".

\section{Conclusion:}

With reference to the results of this study, It is concluded that using SCAMPER strategy in teaching story can enhance primary stage pupils' Creative Speaking Skills. Using SCAMPER strategy also encouraged pupils to speak, enjoy participation in the classroom discussion and motivated them to think divergently in answering various questions.

\section{Recommendations of the study:}

Based on the results and conclusions of the study, the following recommendations are suggested: 
1. EFL teachers of the Ministry of Education should be trained to use SCAMPER strategy in teaching story, in order to help their pupils develop their Creative speaking Skills.

2. Curriculum designers should include SCAMPER strategy in teaching story when developing EFL courses at the primary stage.

3. Providing the Teachers' Books with a guide on how to use SCAMPER strategy in teaching story.

4. Faculty of Education Professors should train pre-service EFL teachers on the use of SCAMPER strategy in teaching story.

5. EFL teachers should train their pupils on how to use SCAMPER strategy when studying in their storybooks.

\section{References:}

Anna, p. (2010) The Effect of Using Language Games on The Speaking Skills of The First Year Students At Industrial Technology of Collage in Bacgiang City (Thesis, Langtauhaste Poly Technic University).

Bakr, M. (2004). The Efficacy of Some Proposed Activities for Developing Creative Thinking of English Learners at the Preparatory stage (Second year). Unpublished Doctoral Dissertation, Faculty of Education University of Cairo.

Becker, C. \& Roos, J.(2016 ). An approach to creative speaking activities in the young learners' classroom. Education Inquiry, vol.7 (1), pp. 9-26.

Brown, D. (2001). Teaching by Principles : An Interactive Approach to Language Pedagogy, San Francisco State University Press.

Diyyab, E. A. (2013). Using a Multimedia-Based Program for Developing Student Teachers' EFL Speaking Fluency Skills. Faculty of Education .Benha University.

Eberele, B. (1987). Scamperon. East Aurora, NYA: D.O.K.

Eberle, B. (1984). Help! In Solving Problems Creatively at Home and School. Carthage, IL: Good Apple, Inc.

Glenn, R. (1997). SCAMPER for Student Creativity. Education Digest, vol. 62 (6), pp. 67-68. 
Graves, K. (2008). The language Curriculum: A social Contextual Perspective. Language Teaching, vol. 41(2), pp. 147-181.

Hughes, R. (2002). Teaching and Researching Speaking. New York: Pearson Education

Hussain, M., \& Carignan, A. (2016). Fourth Graders Make Inventions Using SCAMPER and Animal Adaptation Ideas. Journal of STEM Arts, Crafts, and Constructions vol., 1(2), pp. 48-66.

Hybel, S., \& Richard, L.W.(2001). Communicating effectively. New York McGraw Hill Hinger Education.

Jondeya, S. R., (2011) The Effectiveness Of Using Information Gap on Developing Speaking Skills for The Eight Graders In Gaza. Retrieved from: http://ntdc.alazhar. edu.ps/ upload/e_thesis/ Rania Sameer Jondeya. pd on 15th June 2016.

Kayi, H. (2006).Teaching Speaking. Activities To Promote Speaking in a Second Language. The Internet TESL Journal, vol. XII, (11). Accessed at http://itesIj.org/ Techniques/Kayi-TeachingSpeaking html on 30th June 2016.

Konisheva, A.V. (2008).Games in Foreign Language Teaching: theory and practice. Minsk: Tetra Systems. National Research Tomsk Polytechnic University.

Kovalenko, N. A., \& Smirnova, A. Y. (2015). Self-directed Learning through Creative Activity of Students .Procedia Social and Behavioral Sciences, vol. 166 pp. 393 - 398.

Lindsay, C. \& Knight, P. (2006) Learning and Teaching English. Oxford McDonald, M. R. (1993).The Storytelling Start-up Book. Little Rock: August House.

Michalko, M. (2006) Thinker Toys. A Handbook of Creative Thinking Techniques. Berkeley, Ten Speed Press.

Murdoch, G. (2002). Exploiting Well-known Short Stories for Language Skills Development: Activities to Promote Speaking in a Second Language. The Internet TSL Journal, vol.12 (11).

Nicholas, H., Lightbown, P. M. \& Spada, N. (2001). Recasts as Feedback to Language Learners. Language Learning, vol. 51 (4), pp. 719-758. 
Nunan, D. (1991) Language Teaching Methodology. UK: Prentice Hall International (Chapter two \& three).

Nunan, D. (2003). Practical English language Teaching. Singapore: McGraw Hill.

Nunan, D. (2015). Teaching English to Speakers of Other Languages: An Introduction. Routledge.

Nurhayati, D. A. W. (2016). Using Local Drama in Writing and Speaking: EFL Learners' Creative Expression. of English Language Teaching and Linguistics. Vol. 1 (1).

Rizfi, M. A. (2005). Effective Technical Communication. McGraw Hill.

Starko, A. (2014). Creativity in the Classroom. Schools of Curious Delight. 5th edition. Routledge, New York, NY 10017.

Tilahun, S. ( 2013 ). Assessing The Challenges Of Teaching Speaking Skill In A Large Classroom In Ethiopian Context: The Case of Grade Nine At Arerti Preparatory School, North Shoa Zone. MA Thesis. Haramaya University.

Thornbury, S. (2005a). Awareness, appropriate autonomy. English Language Teaching Professional, vol. 40, p.11-13.

Thornbury, S. (2005b). How to Teach Speaking. Harlow: Pearson Education Limited.

Ur, Penny, H. L. (1996) .Simple Audio visual Aids to Foreign Language Teaching .Oxford : Oxford University Press.

Widiastuti, R. (2008). Teaching Speaking Through Dialogue of the Eleventh Year Students: A Case Study at SMK Muhammadiyah 1 Jatinom Muhammadiyah University of Surkatra. 
